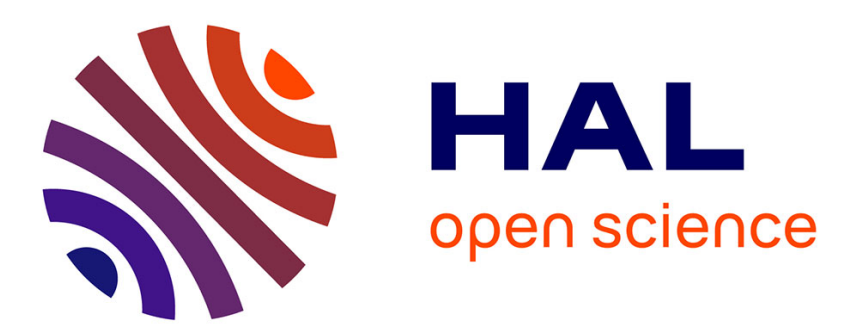

\title{
Paradoxical effects of temperature and solar irradiance on the photodegradation state of killed phytoplankton
}

Remi Amiraux, Christian Jeanthon, Frédéric Vaultier, Jean-Francois Rontani

\section{To cite this version:}

Remi Amiraux, Christian Jeanthon, Frédéric Vaultier, Jean-Francois Rontani. Paradoxical effects of temperature and solar irradiance on the photodegradation state of killed phytoplankton. Journal of Phycology, 2016, 52 (3), pp.475-485. 10.1111/jpy.12410-15-222 . hal-01297771

\section{HAL Id: hal-01297771 \\ https://hal.sorbonne-universite.fr/hal-01297771}

Submitted on 4 Apr 2016

HAL is a multi-disciplinary open access archive for the deposit and dissemination of scientific research documents, whether they are published or not. The documents may come from teaching and research institutions in France or abroad, or from public or private research centers.
L'archive ouverte pluridisciplinaire HAL, est destinée au dépôt et à la diffusion de documents scientifiques de niveau recherche, publiés ou non, émanant des établissements d'enseignement et de recherche français ou étrangers, des laboratoires publics ou privés. 
Received Date : 26-Oct-2015

Revised Date : 10-Feb-2016

Accepted Date : 28-Feb-2016

Article type : Reply

Paradoxical effects of temperature and solar irradiance on the photodegradation state of killed phytoplankton $^{1}$

Remi Amiraux ${ }^{2}$

Aix Marseille Université, CNRS/INSU, Université de Toulon, IRD, Mediterranean Institute of Oceanography (MIO) UM 110, 13288, Marseille, France

Christian Jeanthon

CNRS, UMR 7144, Marine Phototrophic Prokaryotes Team, Station Biologique de Roscoff, 29680

Roscoff, France.

Sorbonne Universités, UPMC Univ Paris 06, UMR 7144, Oceanic Plankton Group, Station

Biologique de Roscoff, 29680 Roscoff, France.

Frédéric Vaultier

Aix-Marseille University, Mediterranean Institute of Oceanography (MIO), 13288, Marseille, Cedex 9; Université du Sud Toulon-Var, 83957, CNRS-INSU/IRD UM 110, France.

Jean-François Rontani

Aix-Marseille University, Mediterranean Institute of Oceanography (MIO), 13288, Marseille, Cedex 9; Université du Sud Toulon-Var, 83957, CNRS-INSU/IRD UM 110, France.

This article has been accepted for publication and undergone full peer review but has not been through the copyediting, typesetting, pagination and proofreading process, which may lead to differences between this version and the Version of Record. Please cite this article as doi: 10.1111/jpy.12410-15-222 
${ }^{1}$ Submitted : October 25, 2015

${ }^{2}$ Correspondence to: R. Amiraux (remi.amiraux@mio.osupytheas.fr), Phone +33635149815

Editorial Responsibility: T. Mock (Associate Editor)

\begin{abstract}
The aim of this paper was to study the effects of temperature and irradiance on the photodegradation state of killed phytoplankton cells. For this purpose, killed cells of the diatom Chaetoceros neogracilis RCC2022 were irradiated (PAR radiations) at 36 and $446 \mathrm{~J} \cdot \mathrm{s}^{-1} \cdot \mathrm{m}^{-2}$ (for a same cumulative dose of irradiation energy) and at two temperatures $\left(7\right.$ and $\left.17^{\circ} \mathrm{C}\right)$. Analyses of specific lipid tracers (fatty acids and sterols) revealed that low temperatures and irradiances increased photooxidative damages of monounsaturated lipids (i.e. palmitoleic acid, cholesterol and campesterol). The high efficiency of type II photosensitized degradation processes was attributed to: (i) the relative preservation of the sensitizer (chlorophyll) at low irradiances allowing a longer production of singlet oxygen and (ii) the slow diffusion rate of singlet oxygen through membranes at low temperatures inducing more damages. Conversely, high temperatures and irradiances induced (i) a rapid degradation of the photosensitizer and a loss of singlet oxygen by diffusion outside the membranes (limiting type II photosensitized oxidation), and (ii) intense autoxidation processes degrading unsaturated cell lipids and oxidation products used as photodegradation tracers. Our results may likely explain the paradoxical relationship observed in situ between latitude and photodegradation state of phytoplankton cells.
\end{abstract}

Key index words: Abiotic degradation ; Autoxidation; Chaetoceros neogracilis; Irradiance; Lipid tracers; PAR; Photooxidation; POM; Temperature. 
Abbreviations: PAR, photosynthetically active radiation; POM; particulate organic matter.

\section{Introduction}

The underlying mechanisms of the carbon cycle such as the degradation of particulate organic matter (POM) have traditionally been studied from a biotic perspective (Vavilin et al. 1996, Wild et al. 2005). However, recent studies demonstrated the importance of abiotic processes (photooxidative and autoxidative) in the marine environment (Rontani et al. 2012a, 2014a). Indeed, chlorophyll, one of the most efficient marine photosensitizers (Foote 1976, Knox and Dodge 1985), can induce type II photosensitized processes. These processes are carried out in the presence of visible or UV light and involve the transfer of light energy from the excited sensitizer to molecular oxygen allowing the formation of a reactive oxygen species (singlet oxygen, ${ }^{1} \mathrm{O}_{2}$ ). When phytoplankton cells are killed, all the energy captured by chlorophyll and originally scheduled for photosynthetic reactions is used to induce type II reactions (less than $1 \%$ when the cells are alive). The rate of ${ }^{1} \mathrm{O}_{2}$ formation can then exceed the quenching capacity of the photoprotective system and photodegradation can occur on common cell components, including unsaturated lipids (unsaturated fatty acids, the phytyl side-chain of chlorophyll, alkenes and $\Delta^{5}$-sterols; Christodoulou et al. 2010, Rontani 2012a), nucleic acids (Dias Cavalcante et al. 2002, Davies 2005) and some amino acids (Nilsson et al. 1972, Michaeli and Feitelson 1994).

The lipid analysis of POM collected in the Beaufort Sea (Arctic Ocean) showed that photooxidative processes are particularly intense in this region (Rontani et al. 2012b). Surprisingly, observed values were one order of magnitude higher than those obtained at lower latitudes (where irradiance and temperature are higher) as in the equatorial Pacific Ocean (Rontani et al. 2011a) or the western Mediterranean Sea (Christodoulou et al. 2009). This relationship observed between latitude and photooxidative damages is unanticipated. Indeed, it is expected that low light intensities decrease photooxidative alterations and low temperatures slow down these reactions. 
The aim of this paper was to study the effects of temperature and solar irradiance on the photodegradation state of killed phytoplankton. For this purpose, we irradiated killed cells of a Chaetoceros neogracilis strain at two irradiances $\left(36\right.$ and $446 \mathrm{~J} \cdot \mathrm{s}^{-1} \cdot \mathrm{m}^{-2}$; for a same cumulative energetic dose) and at 7 and $17^{\circ} \mathrm{C}$. In order to check the effects of photo-adaptation (increase of chlorophyll content with decreasing growth irradiance), photooxidation of cells grown at distinct irradiances and at the same temperature was also investigated. Chlorophyll, lipids and lipid oxidation products were analyzed throughout irradiation.

\section{Material and methods}

\section{Algal cultures}

For each experiment (Fig. 1), we used the non-axenic Chaetoceros neogracilis strain RCC2022 maintained at the Roscoff Culture Collection (Roscoff, France). This strain, isolated from surface waters of the Beaufort Sea in the Arctic Ocean (Balzano et al. 2012, Balzano et al., submitted), was selected based on its ability to grow in a wide range of temperatures $\left(4-17^{\circ} \mathrm{C}\right)$. In this study, two sets of experiments were conducted.

To test the effects of temperature on the photodegradation state of killed phytoplankton, $C$. neogracilis RCC2022 was grown in 1.2 L K medium (Keller et al., 1987) amended with $\mathrm{Na}_{2} \mathrm{SiO}_{3} .9 \mathrm{H}_{2} \mathrm{O}\left(30 \mathrm{mg} \cdot \mathrm{L}^{-1}\right)$ at 7 and $17^{\circ} \mathrm{C}$ in a growth chamber under controlled conditions of temperature and light at an irradiance of $36 \mathrm{~J}^{\cdot} \mathrm{s}^{-1} \cdot \mathrm{m}^{-2}$ (Osram, Fluora, Germany; 12:12 h light:dark cycle). Growth was stopped when the late exponential-early stationary phase was reached.

To test the effects of irradiance on the photodegradation state of killed phytoplankton, $C$. neogracilis $\mathrm{RCC} 2022$ was grown in $600 \mathrm{ml} \mathrm{K}+\mathrm{Si}$ medium at $7^{\circ} \mathrm{C}$, in the same conditions under irradiances of 13 and $6.5 \mathrm{~J} \cdot \mathrm{s}^{-1} \cdot \mathrm{m}^{-2}$ (Fig. 2). 


\section{Photodegradation experiments}

Late exponential-early stationary phase cultures of C. neogracilis RCC2022 grown as described above were killed by adding $\mathrm{HgCl}_{2}$ (Sigma Aldrich, France; $5 \mathrm{mM}$ final concentration) in order to work with homogeneous lots of dead cells and avoid the presence of cells more or less senescent exhibiting distinct reactivities towards photooxidative processes.

In the first experiment (temperature effect), each culture grown at a given temperature was photodegraded at low and high irradiance for the same cumulative dose of irradiation energy. For high irradiance photodegradation experiments, cells were distributed into $100 \mathrm{ml}$ Pyrex flasks and irradiated for $10 \mathrm{~h}$ by artificial light using a solar simulator (Atlas Suntest, USA). High irradiance level was initially set at $500 \mathrm{~J} \cdot \mathrm{s}^{-1} \cdot \mathrm{m}^{-2}$. To eliminate UV radiation, which was absent in low irradiance experiments, a glass plate was placed on the culture flasks, lowering the high irradiance level to $446 \mathrm{~J}$ $\cdot \mathrm{s}^{-1} \cdot \mathrm{m}^{-2}$. The effectiveness of the glass plate to block photons in the UV spectral region was previously validated by comparing the irradiation effects with that obtained using an UV cut-off filter (\% of transmission $<1 \%$ under $395 \mathrm{~nm}$ ). Exposure in the solar simulator for $12 \mathrm{~h}$ at $446 \mathrm{~J} \cdot \mathrm{s}^{-1} \cdot \mathrm{m}^{-2}$ corresponds to a natural daily dose measured at the sea surface in the northwestern Mediterranean region in summer (Abboudi et al. 2008). The flasks were maintained at the growth temperature (7 and $17^{\circ} \mathrm{C}$ ) by submersion in a polyethylene glycol bath connected to a cryothermostat (Huber minichiler, Germany). For low irradiance experiments, cells were distributed into $100 \mathrm{ml}$ Pyrex flasks covered by a glass plate and irradiated at $36 \mathrm{~J} \cdot \mathrm{s}^{-1} \cdot \mathrm{m}^{-2}$ (Osram, Fluora, Germany) for $124 \mathrm{~h}$ in the growth chamber under controlled conditions of temperature. The intensity of the radiant flux produced by the incubator is representative of values observed at deep chlorophyll maximum in the northwestern Mediterranean region (Barbiero and Tuchman 2004).

In the second experiment (irradiance effect), after addition of $\mathrm{HgCl}_{2}$, strains grown under 13 and $6.5 \mathrm{~J} \cdot \mathrm{s}^{-1} \cdot \mathrm{m}^{-2}$ irradiances were photodegraded at $7{ }^{\circ} \mathrm{C}$ under an irradiance of $36 \mathrm{~J} \cdot \mathrm{s}^{-1} \cdot \mathrm{m}^{-2}$ during $124 \mathrm{~h}$ in order to be compared to the strain photodegraded at low irradiance and low temperature in 
the first experiment.

During both experiments, two triplicate samples maintained in the dark during irradiation were used as controls.

\section{Chlorophyll a analysis}

Samples (10 mL) were filtered through $25 \mathrm{~mm}$ GF/F filters (Whatman, UK; previously washed by overnight refluxing in $\mathrm{CH}_{2} \mathrm{Cl}_{2} / \mathrm{MeOH} 2: 1$, v/v; Rathburn, UK) and stored at $-20^{\circ} \mathrm{C}$ until further extraction. Extraction of the filters was performed by addition of $5 \mathrm{~mL}$ of pure $\mathrm{MeOH}$ (Rathburn, UK) and incubation in the dark at $4^{\circ} \mathrm{C}$ for $30 \mathrm{~min}$ according to Raimbault et al. (2004). Fluorescence was directly measured with a Turner Designs fluorimeter (USA) equipped with a F4T5 Blue lamp, a 5-60 $(450 \mathrm{~nm})$ excitation filter and a 2-64 $(660 \mathrm{~nm})$ high-pass emission filter. The fluorimeter was previously calibrated with pure Chlorophyll $a$ (Chl $a$; Sigma, USA) dissolved in $\mathrm{MeOH}(96 \%)$. The Chl $a$ concentration was determined by spectrophotometry using the specific absorption coefficient of $771 \mathrm{~g} \mathrm{~cm}^{-1}$ at $663 \mathrm{~nm}$ (Marker, 1972). For correcting for phaeopigment, the extract was acidified according to the method of Holm-Hansen et al. (1965).

\section{Lipid analysis}

Lipid analysis was performed on $25 \mathrm{~mL}$ of irradiated cultures. To avoid the loss of lipid biomarkers and oxidation products in the dissolved phase (which is increasing with the irradiation time), cells were not filtered through GF/F. Culture samples were submitted to (i) a $\mathrm{NaBH}_{4}$-reduction carried out to reduce labile hydroperoxides resulting from photooxidation and autoxidation to the corresponding alcohols that are amenable to gas chromatography-electron impact mass spectrometry (GC-EIMS) analyses and (ii) a subsequent alkaline hydrolysis allowing the recovery of total lipid extracts. 


\section{Reduction}

Hydroperoxides were reduced to alcohols after addition of $\mathrm{MeOH}(25 \mathrm{~mL})$ and excess $\mathrm{NaBH}_{4}(\mathrm{Sigma}$ Aldrich, France; $10 \mathrm{mg}$ ) to the culture sample and subsequent manual stirring (30 min at room temperature; Marchand and Rontani 2003). During this treatment, ketones are also reduced to their corresponding alcohols and the possibility of some ester cleavage cannot be totally excluded (inducing in our case a loss of fatty acids ranging from 2 to $5 \%$ ).

\section{Alkaline hydrolysis}

Saponification was performed on the reduced samples (Marchand and Rontani 2001, Marchand et al. 2005). After $\mathrm{NaBH}_{4}$ reduction, $2.8 \mathrm{~g}$ of potassium hydroxide (Riedel-de Haën, Germany) were added and the mixture was directly saponified by refluxing for $2 \mathrm{~h}$. The aqueous phase was then acidified (HCl, 2N; Chem Lab, Belgium) and subsequently extracted with $\mathrm{CH}_{2} \mathrm{Cl}_{2}(4 \times 15 \mathrm{~mL})$. The combined extracts were concentrated by rotary evaporation at $40^{\circ} \mathrm{C}$ to give the total lipid fraction.

\section{Derivatization}

Total lipid fractions were taken up in $300 \mu \mathrm{L}$ of pyridine (Sigma Aldrich, France) and bis(trimethylsilyl)trifluoroacetamide (BSTFA, Supelco, France) mixture (2:1, v/v) and silylated at $50^{\circ} \mathrm{C}$ for $1 \mathrm{~h}$ (Pierce, 1982). After evaporation to dryness under nitrogen, the residues obtained were taken up in a suitable volume of a mixture $(1: 1, \mathrm{v} / \mathrm{v})$ of hexane and BSTFA (to avoid desilylation of easily silylated compounds) and analysed by gas chromatography-electron impact mass spectrometry (GC-EIMS).

\section{GC-EIMS analyses}

Lipids and their oxidation products were quantified using an Agilent 7850-A gas chromatograph connected to an Agilent 7000-QQQ mass spectrometer (France). The following conditions were employed: $30 \mathrm{~m}$ x $0.25 \mathrm{~mm}$ (i.d.) fused silica column coated with 
HP-5MS (Agilent; film thickness: $0.25 \mu \mathrm{m}$ ); oven programmed from 70 to $130^{\circ} \mathrm{C}$ at $20^{\circ} \mathrm{C}$ $\min ^{-1}$, then to $250^{\circ} \mathrm{C}$ at $5^{\circ} \mathrm{C} \min ^{-1}$ and then to $300^{\circ} \mathrm{C}$ at $3^{\circ} \mathrm{C} \mathrm{min}^{-1}$; carrier gas (He), 1.0 bar; injector (splitless), $250^{\circ} \mathrm{C}$; electron energy, $70 \mathrm{eV}$; source temperature, $230^{\circ} \mathrm{C}$; quadrupole temperature, $150^{\circ} \mathrm{C} ; \mathrm{m} / \mathrm{z}, 40-700$; collision energy, ranging from 5 to $15 \mathrm{eV}$; collision flow,

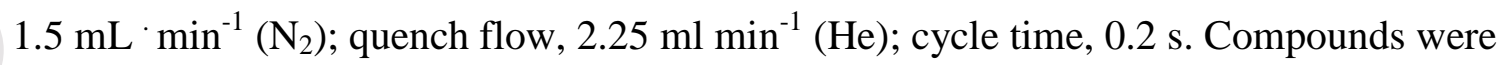
assigned by comparison of retention times and mass spectra with those of standards and quantified (calibration with external standards) with GC-EIMS. For low concentrations or in the case of co-elutions, quantification was achieved using Selected Ion Monitoring (SIM) or Multiple Reaction Monitoring (MRM) modes. The main characteristic mass fragment ions employed to quantify degradation products of sterols have been described previously (Christodoulou et al. 2009, Rontani et al. 2011a).

\section{Lipid degradation products employed for photo- and autoxidation estimation}

It was previously shown (Marchand and Rontani, 2001) that irradiation of dead phytoplanktonic cells resulted in photo- and autoxidation of their unsaturated lipid components. Photosensitized oxidation of monounsaturated fatty acids involves a direct reaction of ${ }^{1} \mathrm{O}_{2}$ with the carbon-carbon double bond by a concerted "ene" addition (Frimer 1979) and leads to the formation of hydroperoxides at each unsaturated carbon. Thus, palmitoleic $\left(\mathrm{C}_{16: 1 \omega 9}\right)$ acid produces a mixture of 9- and 10-hydroperoxides with an allylic trans double bond (Frankel et al. 1998). These two hydroperoxides may undergo highly stereoselective radical allylic rearrangement respectively to 11-trans and 8-trans hydroperoxides (Porter et al. 1995; Fig. 2). In contrast, autoxidation (free radical-induced oxidation) of this acid results to the formation of a mixture of 8-trans, 8-cis, 9-trans, 10-trans, 11-trans and 11cis hydroperoxides, with minor amounts of 9-cis and 10-cis hydroperoxides (Garwood et al. 1977, Frankel et al. 1998) (Fig. 2). Importance of autoxidation was estimated on the basis of the proportion of cis-hydroxyacids (specific of autoxidation) and the temperature of incubation using Eqs. (1-4) previously proposed (Rontani et al. 2011a). The proportion of photoproducts was obtained after 
subtraction of the amounts of trans-hydroxyacids of autoxidative origin.

$([8-c i s]+[11-c i s]) /[9-\operatorname{trans}]=-0.0138 \mathrm{~T}+1.502$

$([8-c i s]+[11-$ cis $]) /[10-$ trans $]=-0.0144 \mathrm{~T}+1.553$

$[8-c i s] /[8-c i s]=[8-$ trans $]=-0.0055 \mathrm{~T}+0.627$

$[11-c i s] /[11-c i s]=[11-$ trans $]=-0.0058 \mathrm{~T}+0.635$

Where $\mathrm{T}$ is the temperature in degree celsius $\left({ }^{\circ} \mathrm{C}\right)$.

Photosensitized oxidation of $\Delta^{5}$-sterols (involving ${ }^{1} \mathrm{O}_{2}$ ) produces mainly $\Delta^{6}-5 \alpha$-hydroperoxides with low amounts of $\Delta^{4}-6 \alpha / 6 \beta$-hydroperoxides (Nickon and Bagli 1961, Kulig and Smith 1973). Due to their high specificity and relative stability, $\Delta^{4}-6 \alpha / 6 \beta$-hydroperoxides were selected as tracers of photooxidation of $\Delta^{5}$-sterols (Christodoulou et al. 2009, Rontani et al. 2009). As they could not be analysed directly by $\mathrm{GC}$, these hydroperoxides were quantified after $\mathrm{NaBH}_{4}$-reduction to the corresponding diols and the sterol photooxidation percentage was estimated using Eq. (5) (Christodoulou et al. 2009), based on the ratio $\Delta^{4}-3 \beta, 6 \alpha / \beta$-hydroperoxides $/ \Delta^{5}-3 \beta, 6 \alpha$-hydroperoxides in biological membranes (0.30) (Korytowski et al. 1992).

Sterol photooxidation $\%=\left(\Delta^{4}-3 \beta, 6 \alpha / \beta\right.$-dihydroxysterol \%) $\times(1+0.3) / 0.3$

Autoxidation of $\Delta^{5}$-sterols yields mainly $7 \alpha$ - and $7 \beta$-hydroperoxides and, to a lesser extent, $5 \alpha / \beta, 6 \alpha / \beta$-epoxysterols and $3 \beta, 5 \alpha, 6 \beta$-trihydroxysterols (Smith 1981). Due to their lack of specificity and/or instability, 7-hydroperoxides and $5 \alpha / \beta, 6 \alpha / \beta$-epoxysterols were discarded as tracers (Christodoulou et al. 2009) and autoxidation was estimated on the basis of $3 \beta, 5 \alpha, 6 \beta$-trihydroxysterol concentrations using Eq. (6) (Rontani et al. 2009) based on autoxidation rate constants previously 
calculated by Morrisey and Kiely (2006).

Sterol autoxidation $\%=(3 \beta, 5 \alpha, 6 \beta$-trihydroxysterols $\%) \times 2.4$

\section{Results}

\section{Lipid composition of C. neogracilis RCC2022}

The major fatty acids of $C$. neogracilis $\mathrm{RCC} 2022\left(\mathrm{C}_{14: 0}, \mathrm{C}_{16: 1 \omega 9}, \mathrm{C}_{16: 0}, \mathrm{C}_{18: 1 \omega 9}\right.$ and $\left.\mathrm{C}_{20: 5}\right)$ are typical of diatoms (Kates and Volcani 1966; Volkman et al., 1989). The fatty acid profile was dominated by palmitoleic $\left(\mathrm{C}_{16: 1 \omega 9}\right)$ and palmitic acids $\left(\mathrm{C}_{16: 0}\right)$, while $\mathrm{C}_{20: 5}$ fatty acid was present in small proportions (less than $2.9 \%$ at $7^{\circ} \mathrm{C}$ and not detected at $17^{\circ} \mathrm{C}$ ). Cholest-5-en-3 $\beta$-ol (cholesterol), 24-methylcholest-

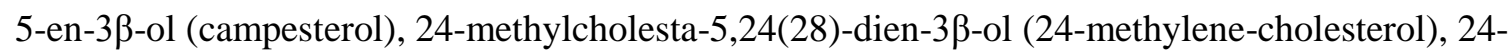

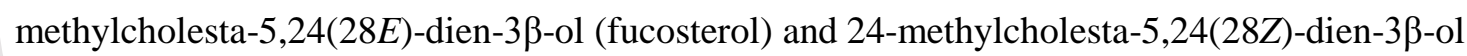
(isofucosterol) represented the main $\Delta^{5}$-sterols. Small proportions $(<10 \%)$ of the corresponding stanols were also detected.

Due to the low proportions of $\mathrm{C}_{20: 5}$ acid and its very high photooxidative and autoxidative reactivities (Frankel 1998, Rontani et al. 1998), it was not possible to test the effect of temperature and irradiance on its photodegradation kinetics. For the same reasons, it was not possible to monitor the photodegradation of fucosterol and iso-fucosterol. Due to the coelution of 24-methylenecholesterol with the isobaric campestanol, this diunsaturated sterol could not be used as tracer during our experiments.

Deconvolution of the effects of temperature and irradiance on the photooxidation of killed cells of C. neogracilis RCC2022 was thus carried out using the following unsaturated lipid tracers: chlorophyll phytyl side-chain, $\mathrm{C}_{16: 1 \omega 9}$ fatty acid, cholesterol and campesterol. These effects were assessed by: i) monitoring directly the degradation of these tracers or ii) quantifying the production of their oxidation products. 


\section{Degradation rate of lipid extracts}

Analysis of the photochemical degradation state of lipid extracts obtained after cells were grown at the same irradiance (Fig. 1) showed a strong photodegradation of most unsaturated lipid components whatever the temperature or irradiance applied. The rates of degradation were well represented by pseudo first-order kinetics, which are not dependent on initial lipid concentrations. This allowed an easier comparison of the different photodegradation constants obtained.

\section{Chlorophyll and phytyl side-chain}

Differences of reactivity between $\mathrm{Chl} a$ tetrapyrrolic structure and its phytyl side-chain were from 6 to 15 times higher in C. neogracilis RCC2022 than those previously reported in other diatoms and in coccolithophores where they did not differ by more than 3 to 5 times (Cuny et al., 1999;

Christodoulou et al., 2010). The highest degradation constants were observed at high irradiance and low temperature $\left(5.67 \times 10^{-3}\right.$ and $8.66 \times 10^{-4} \cdot \mathrm{KJ}^{-1} \cdot \mathrm{m}^{2}$ for Chl $a$ and its phytyl chain, respectively; Table 1). The increase of temperature strongly decreased degradation rates at high irradiance but the effect was not substantial at low irradiance. Photochemical and non-photochemical (mainly thermal) degradations were distinguished by using dark controls. Non-photochemical rate constants were more than one order of magnitude lower than photochemical constants (Table 1).

Monounsaturated fatty acids and $\Delta^{5}$-sterols

Photodegradation of cholesterol, campesterol and palmitoleic acid followed similar trends, i.e. highest degradation at low irradiance and low temperature and weakest degradation at high irradiance and high temperature (Table 2). Moreover, degradation rate constants were always stronger at $7^{\circ} \mathrm{C}$ than at $17^{\circ} \mathrm{C}$ whatever the light exposure. 
After all irradiation experiments, a significant amount of oxidation products was observed. The pattern of palmitoleic degradation products after irradiation at low irradiance was mainly composed of 8-hydroxyheptadec-9(trans)-enoic, 10-hydroxyheptadec-8(trans)-enoic, 9-hydroxyheptadec11(trans)-enoic and 11-hydroxyheptadec-9(trans)-enoic acids (Fig. 3A) resulting from photooxidative degradation and subsequent allylic rearrangement (see section 2.4.5). In contrast, at high irradiance, we observed the presence of substantial proportions of additional 8-hydroxyheptadec-9(cis)-enoic, and 11-hydroxyheptadec-9(cis)-enoic (ratios 8-cis/8-trans $=0.9$ and 11-cis/11-trans $=1.2$; Fig. 3B) attesting to the involvement of autoxidative degradation processes. Similarly to palmitoleic acid, the pattern of sterol degradation products after low irradiation showed high $\left(\Delta^{4}-3 \beta, 6 \alpha / \beta\right.$ -

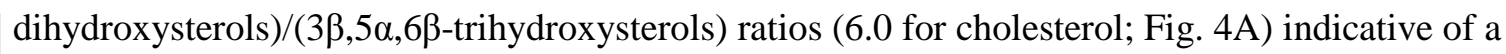
dominance of photooxidative processes (see section 2.5.5). The contrary was observed after high irradiation (0.3 for cholesterol; Fig. 4B).

\section{Effects of cell content}

In order to determine the effects of photo-adaptation and more particularly of the chlorophyll (sensitizer) content, which increases with decreasing growth irradiance, C. neogracilis RCC2022 was grown at $7^{\circ} \mathrm{C}$ under different irradiances, before being photodegraded.

As it was previously demonstrated (Helbling et al. 1996), chlorophyll content increased significantly with decreasing irradiance $\left(6.38 \times 10^{-7}, 5.45 \times 10^{-7}\right.$ and $4.55 \times 10^{-7} \mu \mathrm{g}$ cell ${ }^{-1}$ at $6.5,13$ and 36 $\mathrm{J} \cdot \mathrm{s}^{-1} \cdot \mathrm{m}^{-2}$, respectively; Table 3). Despite the presence of decreasing amounts of sensitizer in cells, the degradation rates of palmitoleic acid, cholesterol and campesterol increased significantly with irradiance (Table 3). 


\section{Discussion}

Sensitivity of phytoplankton lipids to photo- and autoxidative processes

Analyses of the lipid compounds of the diatom C. neogracilis RCC2022 after irradiation revealed that chlorophyll and phytyl side-chain photodegradation rates were higher at low temperature and high irradiance, while photodegradation of other lipids (palmitoleic acid, cholesterol and campesterol) prevailed at low temperature and low irradiance (Table 2).

However, the highest degradation of these compounds observed at lower temperatures could also result from the higher chlorophyll content of cells grown under these conditions $\left(4.55 \times 10^{-7}\right.$ and $3.70 \times 10^{-7} \mu \mathrm{g}$ cell $^{-1}$ at 7 and $17^{\circ} \mathrm{C}$, respectively; Table 1$)$. In order to determine if chlorophyll content could impact photosensitized oxidation rates of the different lipids, irradiations were carried out under the same conditions $\left(7^{\circ} \mathrm{C}\right.$ and $\left.36 \mathrm{KJ}^{\cdot} \mathrm{s}^{-1} \cdot \mathrm{m}^{-2}\right)$ with cells containing different pigment concentrations (i.e., grown at $7^{\circ} \mathrm{C}$ but under distinct irradiations) (Fig. 1). The results obtained (Table 3) allowed us to refute the assumption that the cell contents in sensitizer and more generally in pigments (contribution of photoprotective pigments to total pigments constant for the three conditions) play a role in lipid degradation rate variations.

Due to its high sensitizer properties, chlorophyll induces type II photosensitized reactions and the singlet oxygen thus formed can degrade most of the cellular components, including unsaturated lipids (for a review see Rontani 2012a), some amino-acids (Nilsson et al. 1972, Michaeli and Feitelson 1994), nucleic acids (Dias Cavalcante et al. 2002, Davies 2005) and chlorophyll itself (Van Hasselt 1974). Chlorophyll can also undergo direct photochemical degradation (Zafiriou et al. 1984). The difference in reactivity observed between chlorophyll and the other lipids (Table 2) thus comes from additional direct photodegradation mechanisms, which should logically increase with increasing PAR irradiance. 
Surprisingly, unsaturated fatty acids and sterol exhibited highest photodegradation rate constants at low irradiance and low temperature (Table 2). It may be noted that low irradiances preserve chlorophyll (sensitizer), which is thus able to produce ${ }^{1} \mathrm{O}_{2}$ in cell membranes for long time periods. Moreover, it was previously shown that low temperatures decrease the diffusion rate of ${ }^{1} \mathrm{O}_{2}$ through membranes (Ehrenberg et al. 1998). The combination of these two processes should thus result in an intense photosensitized degradation of all unsaturated lipids.

Recent studies have shown that in phytoplanktonic membranes, monounsaturated fatty acids are photodegraded (via type II photosensitized reactions) at similar rates than the chlorophyll phytyl sidechain, but faster than $\Delta^{5}$-sterols (Rontani et al. 1998, Rontani et al. 2011b). The lowest reactivity of $\Delta^{5}$-sterols was attributed to steric hindrance during the attack of their double bond by ${ }^{1} \mathrm{O}_{2}$ (Beutner et al., 2000). The difference of more than an order of magnitude observed between palmitoleic acid and chlorophyll phytyl side-chain photodegradation rates in the case of $C$. neogracilis RCC2022 (Table 2) was attributed to the partial localization of this acid in the cytoplasm of the cells of this diatom. Indeed, it is interesting to note that photodegradation of palmitoleic acid has been studied in situ in sea ice diatoms (Rontani et al. 2014a). The resistance of this compound to photooxidation (relative to phytyl side-chain and $\Delta^{5}$-sterols) was attributed to the location of palmitoleic acid in cytoplasmic inclusions (Smith et al. 1993, 1997), where efficient transfer of ${ }^{1} \mathrm{O}_{2}$ from chloroplastic compartments seems unlikely. Indeed, many diatoms (and notably Chaetoceros species) have the ability to produce highest proportions of triacylglycerols (TAGs) as storage lipids during stationary phase of growth (Gong et al. 2013). These TAGs (often enriched in palmitoleic acid; Falk-Petersen et al. 1998, Henderson et al.1998) accumulate as cytosolic lipid bodies in order to store energy to cope stress conditions. 


\section{Degradation products of unsaturated lipids degradation process}

Our results clearly showed that the degradation of unsaturated lipids results from photooxidative and autoxidative processes acting in different proportions depending on temperature and irradiance conditions. Thus, photooxidation was predominant when temperature and irradiance were low, while autoxidation was mostly involved in the degradation processes at high irradiance and high temperature (Table 2). It may be noted that if increasing temperatures enhance the efficiency of autoxidative radical chain reactions during irradiation (Table 2), they did not induce measurable thermal degradation of the lipids investigated in dark controls in the range of temperature tested (7$17^{\circ} \mathrm{C}$ ). Initiation of autoxidative process was thus attributed to homolytic cleavage of photochemically-produced hydroperoxides (Girotti, 2001, Rontani et al. 2003), which may be favored under high temperatures (Chaiyasit et al. 2007) and high irradiances of visible light (Foote 1995, Chaiyasit et al. 2007). Comparison of the proportion of oxidation products (relative to the parent compound) after incubation at high and low temperatures and irradiances (Figs. 3 and 4) clearly showed the autoxidative consumption of oxidation products, supporting well this assumption.

In the case of monounsaturated fatty acids, the proposed distinction between photo- and autoxidation is based on measurement of the proportion of specific autoxidative cis allylic hydroxyacids (Marchand and Rontani 2001, Rontani et al. 2011a), while those of $\Delta^{5}$-sterol involves $\Delta^{4}-3 \beta, 6 \alpha / \beta$-dihydroxysterols (photooxidation tracers) and $3 \beta, 5 \alpha, 6 \beta$-trihydroxysterols (autoxidation tracers; Christodoulou et al. 2009, Rontani et al. 2009). Interestingly, these two well distinct methods gave very similar values (Table 2; variation lower than 6\%).

In high-latitude areas, low temperatures and irradiances should thus lead to a long and intense production of singlet oxygen causing very strong photooxidative damages on unsaturated cell components of phytoplankton. Furthermore, due to the weak involvement of autoxidative processes, the preservation of photooxidation products of monounsaturated lipids (used as tracers of photooxidative processes) should be favored. The combination of these different processes allows to 
explain the exacerbation of phytoplankton photooxidation previously observed in Arctic (Rontani et al. 2012a).

In contrast, at low latitudes, high irradiances should induce rapid photodegradation of the sensitizer, while relatively high temperatures should favour diffusion of ${ }^{1} \mathrm{O}_{2}$ outside the cells. Moreover, these two parameters should also induce an intense autoxidative degradation of photooxidation products of monounsaturated compounds. As the result of these different processes, photooxidation of phytoplankton in equatorial zones should appear less favored than in polar zones. This assumption is well supported by photooxidation estimates obtained at different latitudes (Christodoulou et al. 2009, Rontani et al. 2011a, 2012a). However, it may be noted that the relative preservation of monounsaturated lipids at low latitudes does not allow to exclude a significant photodegradation of polyunsaturated lipids, which are highly reactive towards photooxidation processes, but produce degradation products insufficiently stable to be used as tracers.

\section{Conclusion}

Our study showed that photodegradation rates of monounsaturated lipid components increased with decreasing temperatures and irradiances in killed cells of $C$. neogracilis RCC2022. We suggest that these results can likely be attributed to the relative preservation of the sensitizer (chlorophyll) at low irradiances resulting in a longer production of singlet oxygen and a slower diffusion rates of singlet oxygen through the membranes at low temperatures, allowing intense type II photosensitized reactions. In addition to an increase of the rates of: (i) chlorophyll photodegradation (limiting the duration of singlet oxygen production) and (ii) diffusion of singlet oxygen outside the membranes (limiting the efficiency of its damages), high irradiances and temperatures induce the involvement of autoxidation. These abiotic processes are not only competitive with photooxidative processes, but also result in a degradation of the oxidation products employed as tracers of photodegradative processes. 
Together, these results explain the exacerbation of photooxidative state of POM observed at high latitudes (low irradiance and temperature; Rontani et al. 2012a) and the lower values obtained in equatorial zones (Rontani et al. 2011a).

Likewise, the effects of irradiance and temperature demonstrated here could also explain the differences of photooxidation state observed between aquatic and higher terrestrial plants in temperate zones (Rontani et al. 2014b). Indeed, at these latitudes aquatic plants are subjected to significantly lower temperatures and irradiances than higher terrestrial plants.

\section{Ackowledgements}

This work was carried out in the framework of the transverse axis DEBAT (DEgradation Biotique et Abiotique de la maTière organique en milieu marin: processus et interactions) of the MIO. It was supported by a CNRS grant (Micromar, INSU-EC2CO Microbien program) and by the GreenEdge project funded by the following French and Canadian programs and agencies: ANR (Contract \#111112), CNES (project \#131425), LEFE, IPEV (project \#1164), CSA and ArcticNet. The GreenEdge project is conducted under the scientific coordination of the Canadian Excellence Research Chair on Remote Sensing of Canada's new Arctic frontier and the CNRS \& Université Laval Joint International laboratory Takuvik (UMI3376). We thank the Oceanomed project (FEDER $\left.\mathrm{n}^{\circ} 1166-39417\right)$. We also thank J. Ras and C. Dimier from the SAPIGH analytical platform of the Laboratoire d'Océanographie de Villefranche (CNRS-France) and P. Raimbault and N. Garcia from the PAPB analytical platform of the Mediterranean Institute of oceanography (France) for pigment analyses.

\section{References}

Abboudi, M., Matallana Surget, S., Rontani, J.F., Sempéré, R. \& Joux, F. 2008. Physiological alteration of the marine bacterium Vibrio angustum S14 exposed to simulated sunlight during 
growth. Curr. Microbiol. 57:412-7.

Balzano, S., Marie, D., Gourvil, P. \& Vaulot, D. 2012. Composition of the summer photosynthetic pico and nanoplankton communities in the Beaufort Sea assessed by T-RFLP and sequences of the 18S rRNA gene from flow cytometry sorted sample. ISME J. 6:1480-1498.

Balzano, S., Percopo, I., Siano, R., Gourvil, P. Chanoine M., Marie, D., Vaulot, D. \& Sarno, D. 2015. Diatom diversity in the Beaufort Sea (Canadian Arctic). Submitted.

Barbiero, R.P. \& Tuchman, M.L. 2004. The deep chlorophyll maximum in Lake Superior. J. Great Lakes Res. 30, Supplement 1:256-68.

Beutner, S., Bloedorn, B., Hoffmann, T. \& Martin, H.D. 2000. [22] Synthetic singlet oxygen quenchers. In Methods in Enzymology. Elsevier, pp. 226-41.

Cavalcante, A.K.D., Martinez, G.R., Di Mascio, P., Menck, C.F.M. \& Agnez-Lima, L.F. 2002. Cytotoxicity and mutagenesis induced by singlet oxygen in wild type and DNA repair deficient Escherichia coli strains. DNA Repair. 1:1051-6.

Chaiyasit, W., Elias, R.J., McClements, D.J. \& Decker, E.A. 2007. Role of physical structures in bulk oils on lipid oxidation. Crc. cr. rev. food. sci. 47:299-317.

Christodoulou, S., Joux, F., Marty, J.C., Sempéré, R. \& Rontani, J.-F. 2010. Comparative study of UV and visible light induced degradation of lipids in non-axenic senescent cells of Emiliania huxleyi. Mar. Chem. 119:139-52.

Christodoulou, S., Marty, J.C., Miquel, J.C., Volkman, J.K. \& Rontani, J.F. 2009. Use of lipids and their degradation products as biomarkers for carbon cycling in the northwestern Mediterranean Sea. Mar. Chem. 113:25-40.

Cuny, P., Romano, J.C., Beker, B. \& Rontani, J.-F. 1999. Comparison of the photodegradation rates of chlorophyll chlorin ring and phytol side chain in phytodetritus: is the phytyldiol versus phytol ratio (CPPI) a new biogeochemical index? J. Exp. Mar. Biol. Ecol. 237:271-90. 
Davies, M.J. 2005. The oxidative environment and protein damage. Biochimica et Biophysica Acta (BBA) - Proteins and Proteomics. 1703:93-109.

Ehrenberg, B., Anderson, J.L. \& Foote, C.S. 1998. Kinetics and yield of singlet oxygen photosensitized by hypericin in organic and biological media. Photochem. Photobiol. 68:13540.

Falk-Petersen, S., Sargent, J.R., Henderson, J., Hegseth, E.N., Hop, H. \& Okolodkov, Y.B. 1998. Lipids and fatty acids in ice algae and phytoplankton from the marginal ice zone in the Barents Sea. Polar Biol. 20:41-7.

Foote, C.S. 1976. Photosensitized oxidation and singlet oxygen: consequences in biological systems. Free radicals in biology 2:85-133.

Foote, C.S. 1995. Active oxygen in chemistry. Springer Science \& Business Media.

pp.

Frankel, E.N., 1998. Lipid oxidation. The Oily Press, Dundee.

Frimer, A.A. 1979. The reaction of singlet oxygen with olefins: the question of mechanism. Chem. Rev. 79:359-87.

Garwood, R.F., Khambay, B.P.S., Weedon, B.C.L. \& Frankel, E.N. 1977. Allylic hydroperoxides from the autoxidation of methyl oleate. J.Chem. Soc. Chemical Communications. 364.

Girotti, A.W. 2001. Photosensitized oxidation of membrane lipids: reaction pathways, cytotoxic effects, and cytoprotective mechanisms. J. Photoch. Photobio. B. 63:103-13.

Gong, Y., Zhang, J., Guo, X., Wan, X., Liang, Z., Hu, C.J. \& Jiang, M. 2013. Identification and characterization of PtDGAT2B, an acyltransferase of the DGAT2 acyl-coenzyme a: diacylglycerol acyltransferase family in the diatom Phaeodactylum tricornutum. FEBS Lett. 587:481-7.

Helbling, E.W., Chalker, B.E., Dunlap, W.C., Holm-Hansen, O. \& Villafañe, V.E. 1996. 
Photoacclimation of antarctic marine diatoms to solar ultraviolet radiation. J. Exp. Mar. Biol. Ecol. 204:85-101.

Henderson, R.J., Hegseth, E.N., Park, R.T. 1998. Seasonal variation in lipid and fatty acid composition of ice algae from the Barents Sea. Polar Biol. 20, 48-55.

Holm-Hansen, O., Lorenzen, C.J., Holmes, R.W. \& Strickland, J.D.H. 1965. Fluorometric determination of chlorophyll. J. Cons. Int. Explor. Mer. 30:3-15.

Kates, M. \& Volcani, B.E. 1966. Lipid components of diatoms. Biochimica et Biophysica Acta (BBA) - Lipids and Lipid Metabolism. 116:264-78.

Keller, M.D., Selvin, R.C., Claus, W. \& Guillard, R.R.L. 1987. Media for the culture of oceanic ultraphytoplankton. J. Phycol. 23: 633-638.

Knox, J.P. \& Dodge, A.D. 1985. Singlet oxygen and plants. Phytochemistry 24:889-96.

Korytowski, W., Bachowski, G.J. \& Girotti, A.W. 1992. Photoperoxidation of cholesterol in homogeneous solution, isolated membranes, and cells : comparison of the $5 \alpha$ - and $6 \beta$ hydroperoxides as indicators of singlet oxygen intermediacy. Photochem. and Photobiol. $56: 1-8$.

Kulig, M.J. \& Smith, L.L. 1973. Sterol metabolism. XXV. Cholesterol oxidation by singlet molecular oxygen. The Journal of Organic Chemistry. 38:3639-42.

Marchand, D., Marty, J.C., Miquel, J.C. \& Rontani, J.-F. 2005. Lipids and their oxidation products as biomarkers for carbon cycling in the northwestern Mediterranean Sea: results from a sediment trap study. Mar. Chem. 95:129-47.

Marchand, D. \& Rontani, J.F. 2001. Characterisation of photooxidation and autoxidation products of phytoplanktonic monounsaturated fatty acids in marine particulate matter and recent sediments. Org. Geochem. 32:287-304. 
Marchand, D. \& Rontani, J.F. 2003. Visible light-induced oxidation of lipid components of purple sulfur bacteria: a significant process in microbial mats. Org. Geochem. 34:61-79.

Marker, A.F.H. 1972. The use of acetone and methanol in the estimation of chlorophyll in the presence of phaeophytin. Freshwater Biol. 2:361-85.

Michaeli, A. \& Feitelson, J. 1994. Reactivity of singlet oxygen toward amino acids and peptides. Photochem. and Photobiol. 59:284-9.

Morrissey, P.A. \& Kiely, M. 2006. Oxysterols: formation and biological function. In Fox, P. F. \& McSweeney, P. L. H. [Eds.] Advanced Dairy Chemistry Volume 2 Lipids. Springer US, pp. $641-74$.

Nickon A, Bagli JF. 1961. Reactivity and geometry in allylic systems. I. Stereochemistry of photosensitized oxygenation of monoölefins 1,2. J. Am. Chem. Soc. 83:1498-508.

Nilsson, R., Merkel, P.B. \& Kearns, D.R. 1972. Unambiguous evidence for the participation of singlet oxygen $(\delta)$ in photodynamic oxidation of amino acids. Photochem. and Photobiol. $16: 117-24$.

Pierce, A.E., 1982. Silylation of organic compounds. Rockford, Illinois.

Porter, N.A., Caldwell, S.E., Mills, K.A., 1995. Mechanisms of free radical oxidation of unsaturated lipids. Lipids 30:277-290.

Raimbault, P., Lantoine, F. \& Neveux, J. 2004. Dosage rapide de la chlorophylle a et des phéopigments a par fluorimétrie après extraction au méthanol. Comparaison avec la méthode classique d'extraction à l'acétone. Océanis. 30:189-205.

Rontani, J.F., Belt, S.T., Brown, T.A., Vaultier, F. \& Mundy, C.J. 2014a. Sequential photo- and autoxidation of diatom lipids in Arctic sea ice. Org. Geochem. 77:59-71.

Rontani, J.-F., Belt, S.T., Vaultier, F. \& Brown, T.A. 2011b. Visible light induced photooxidation of highly branched isoprenoid (HBI) alkenes: Significant dependence on the number and 
nature of double bonds. Org. Geochem. 42:812-22.

Rontani, J.F., Charriere, B., Forest, A., Heussner, S., Vaultier, F., Petit, M., Delsaut, N. et al. 2012a. Intense photooxidative degradation of planktonic and bacterial lipids in sinking particles collected with sediment traps across the Canadian Beaufort Shelf (Arctic Ocean). Biogeosciences. 9:4787-802.

Rontani, J.F., Charriere, B., Petit, M., Vaultier, F., Heipieper, H.J., Link, H., Chaillou, G. et al. 2012b. Degradation state of organic matter in surface sediments from the Southern Beaufort Sea: a lipid approach. Biogeosciences 9:3513-30.

Rontani, J.F., Cuny, P. \& Grossi, V. 1998. Identification of a "pool” of lipid photoproducts in senescent phytoplanktonic cells. Org. Geochem. 29:1215-25.

Rontani, J.F., Rabourdin, A., Marchand, D. \& Aubert, C. 2003. Photochemical oxidation and autoxidation of chlorophyll phytyl side chain in senescent phytoplanktonic cells: Potential sources of several acyclic isoprenoid compounds in the marine environment. Lipids. 38:24154.

Rontani, J.F., Vaultier, F. \& Bonin, P. 2014b. Biotic and abiotic degradation of marine and terrestrial higher plant material in intertidal surface sediments from Arcachon Bay (France): A lipid approach. Mar. Chem. 158:69-79.

Rontani, J.F., Zabetia, N. \& Wakeham, S.G. 2011a. Degradation of particulate organic matter in the equatorial Pacific Ocean: Biotic or abiotic? Limnol. Oceanogr. 56:333-49.

Rontani, J.F., Zabeti, N. \& Wakeham, S.G. 2009. The fate of marine lipids: Biotic vs. abiotic degradation of particulate sterols and alkenones in the Northwestern Mediterranean Sea. Mar. Chem. 113:9-18.

Smith, L.L. 1981. Other oxidations in cholesterol autoxidation. (Springer: New York) pp 243-295.

Smith, R.E.H., Cavaletto, J.F., Eadie, B.J., Gardner, W.S., 1993. Growth and lipid composition of 
high Arctic ice algae during the spring bloom at Resolute, Northwest Territories, Canada. Mar. Ecol. Prog. Ser. 97:19-29.

Smith, R.E.H., Gosselin, M., Kudoh, S., Robineau, B., Taguchi, S., 1997. DOC and its relationship to algae in bottom ice communities. J. Marine Syst. 11:71-80.

Van Hasselt, P.R. 1974. Photooxidation of unsaturated lipids in cucumis leaf discs during chilling. Acta Botanica Neerlandica. 23:159-69.

Vavilin, V.A., Rytov, S.V. \& Lokshina, L.Y. 1996. A description of hydrolysis kinetics in anaerobic degradation of particulate organic matter. Bioresource Technol. 56:229-37.

Volkman, J.K., Jeffrey, S.W., Nichols, P.D., Rogers, G.I. \& Garland, C.D. 1989. Fatty acid and lipid composition of 10 species of microalgae used in mariculture. J. Exp. Mar. Biol. Ecol. 128:219-40.

Wild, C., Rasheed, M., Jantzen, C., Cook, P., Struck, U., Huettel, M. \& Boetius, A. 2005. Benthic metabolism and degradation of natural particulate organic matter in carbonate and silicate reef sands of the northern Red Sea. Mar. Ecol. Prog. Ser. 298:69-78.

Zafiriou, O.C., Joussot-Dubien, J., Zepp, R.G. \& Zika, R.G. 1984. Photochemistry of natural waters. Environ. Sci. Technol. 18:358A - 371A.

Figure captions

Fig. 1. Summary of C. neogracilis degradation experiment.

Fig. 2. Hydroperoxides resulting from autoxidation and type II photooxidation of palmitoleic acid. 
Fig. 3. Partial MRM chromatograms (transitions $m / z 199 \rightarrow m / z$ 129, $m / z 329 \rightarrow m / z$ 149, $m / z 213 \rightarrow$ $m / z 129, m / z \quad 343 \rightarrow m / z 163, m / z 311 \rightarrow m / z$ 131) of silylated $\mathrm{NaBH}_{4}$ reduced saponified fractions showing the presence of palmitoleic oxidation products after low (A) and strong (B) PAR exposures.

Fig. 4. Partial $\mathrm{m} / \mathrm{z}$ 403, 458 mass fragmentograms of silylated $\mathrm{NaBH}_{4}$ reduced saponified fractions showing the presence of cholesterol oxidation products after low (A) and strong (B) PAR exposures.

Table 1. First-order rate constants and half-life doses $\left(\mathrm{D}_{1 / 2}\right)$ for light and temperature-dependent degradation of chlorophyll and its phytyl side-chain in killed C. neogracilis cells.

Table 2. Photooxidative first-order rate constants and relative percentages of photo- and autoxidation of monounsaturated lipid components of killed Chaetoceros neogracilis cells.

Table 3. Chlorophyll, phytol and palmitoleic first-order degradation rate constants, chlorophyll per cell, carotenoid, and sterol relative percentage of photooxidation for Chaetoceros neogracilis grown at similar temperature $\left(7^{\circ} \mathrm{C}\right)$ but different irradiances, before being photodegraded in the same conditions $\left(7^{\circ} \mathrm{C}\right.$ and $\left.36 \mathrm{~J} \cdot \mathrm{s}^{-1} \cdot \mathrm{m}^{-2}\right)$. 
Table 1. First-order rate constants and half-life doses $\left(\mathrm{D}_{1 / 2}\right)$ for light and temperature-dependent degradation of chlorophyll and its phytyl side-chain in killed C. neogracilis cells.

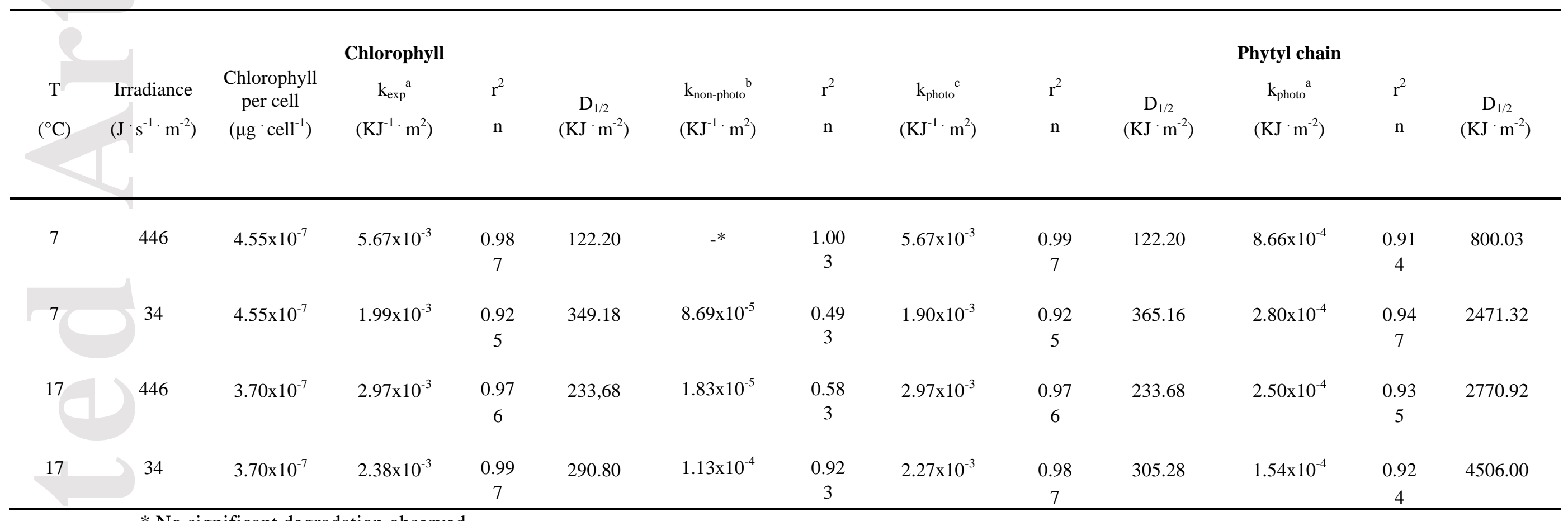

* No significant degradation observed

Pseudo first order degradation rate constants.

${ }^{\mathrm{b}}$ Pseudo first order degradation rate constants in dark controls.

Obtained after subtraction of non-photochemical degradation rate constants. 
Table 2. Photo-oxidative first-order rate constants and relative percentages of photo- and autoxidation of monounsaturated lipid components of killed Chaetoceros neogracilis cells.

${ }^{a}$ Discerned owing to the proportion of specific autoxidative cis allylic 8- and 11-hydroxyacids (resulting from $\mathrm{NaBH}_{4}$-reduction of the corresponding

\begin{tabular}{|c|c|c|c|c|c|c|c|c|c|c|c|c|c|}
\hline & & Palmitoleic ac & & & & Cholesterol & & & & Campesterol & & & \\
\hline $\begin{array}{c}\mathrm{T} \\
\left({ }^{\circ} \mathrm{C}\right)\end{array}$ & $\begin{array}{l}\text { Irradiance } \\
\left(\begin{array}{c}\mathrm{J}^{\prime} \mathrm{s}^{-1} \cdot \mathrm{m}^{-} \\
2\end{array}\right)\end{array}$ & $\begin{array}{c}\text { Photo- } \\
\text { oxidation } \\
(\text { relative } \%)^{\mathrm{a}}\end{array}$ & $\begin{array}{c}\text { Auto- } \\
\text { oxidation } \\
(\text { relative \%) }\end{array}$ & $\begin{array}{c}\mathrm{k}_{\text {photo }} \mathrm{b} \\
\left(\mathrm{KJ}^{-1} \cdot \mathrm{m}^{2}\right)\end{array}$ & $\begin{array}{l}\mathrm{r}^{2} \\
\mathrm{n}\end{array}$ & $\begin{array}{c}\begin{array}{c}\text { Photo- } \\
\text { oxidation }\end{array} \\
(\text { relative } \%)^{\mathrm{c}}\end{array}$ & $\begin{array}{c}\begin{array}{c}\text { Auto- } \\
\text { oxidation }\end{array} \\
(\text { relative } \%)^{\mathrm{d}}\end{array}$ & $\begin{array}{l}\mathrm{k}_{\text {photo }}{ }^{\mathrm{e}} \\
\left(\mathrm{KJ}^{-1}\right. \\
\left.\mathrm{m}^{2}\right)\end{array}$ & $\begin{array}{l}\mathrm{r}^{2} \\
\mathrm{n}\end{array}$ & $\begin{array}{c}\begin{array}{c}\text { Photo- } \\
\text { oxidation }\end{array} \\
(\text { relative } \%)^{\mathrm{c}}\end{array}$ & $\begin{array}{c}\text { Auto- } \\
\text { oxidation } \\
\text { (relative } \\
\%)^{\mathrm{d}}\end{array}$ & $\begin{array}{c}\mathrm{k}_{\text {photo }} \mathrm{e} \\
\left(\mathrm{KJ}^{-1} \cdot \mathrm{m}^{2}\right)\end{array}$ & $\begin{array}{l}\mathrm{r}^{2} \\
\mathrm{n}\end{array}$ \\
\hline 7 & 446 & $79 \pm 5$ & $21 \pm 5$ & $1.22 \times 10^{-4}$ & $\begin{array}{c}0.91 \\
7\end{array}$ & $79 \pm 1$ & $21 \pm 1$ & $9.20 \times 10^{-5}$ & $\begin{array}{c}0.96 \\
5\end{array}$ & $69 \pm 3$ & $31 \pm 3$ & $9.00 \times 10^{-5}$ & $\begin{array}{c}0.94 \\
6\end{array}$ \\
\hline 7 & 36 & $91 \pm 1$ & $9 \pm 1$ & $1.68 \times 10^{-4}$ & $\begin{array}{c}0.95 \\
7\end{array}$ & $91 \pm 1$ & $9 \pm 1$ & $8.30 \times 10^{-5}$ & $\begin{array}{c}0.93 \\
5\end{array}$ & $87 \pm 1$ & $13 \pm 1$ & $1.10 \times 10^{-4}$ & $\begin{array}{c}0.99 \\
6\end{array}$ \\
\hline 17 & 446 & $30 \pm 1$ & $70 \pm 1$ & $2.47 \times 10^{-5}$ & $\begin{array}{c}0.97 \\
5\end{array}$ & $35 \pm 2$ & $65 \pm 2$ & 0 & $\begin{array}{c}1.00 \\
5\end{array}$ & $33 \pm 5$ & $67 \pm 5$ & $1.36 \times 10^{-5}$ & $\begin{array}{c}0.91 \\
5\end{array}$ \\
\hline 17 & 36 & $75 \pm 5$ & $25 \pm 5$ & $8.10 \times 10^{-5}$ & $\begin{array}{c}0.98 \\
4\end{array}$ & $77 \pm 6$ & $23 \pm 6$ & $2.20 \times 10^{-5}$ & $\begin{array}{c}0.71 \\
5\end{array}$ & $74 \pm 4$ & $26 \pm 4$ & $5.50 \times 10^{-5}$ & $\begin{array}{c}0.84 \\
4\end{array}$ \\
\hline
\end{tabular}

hydroperoxyacids) (Marchand and Rontani 2001, Rontani et al. 2011)

${ }^{\mathrm{b}}$ Pseudo first order photooxidation rate constant $=$ (pseudo first order degradation of palmitoleic $\mathrm{x}$ photooxidation percentage).

Sterol photooxidation \% estimated with the equation $\left(\Delta^{4}-3 \beta, 6 \alpha / \beta\right.$-dihydroxycholesterols \% x $\left.(1+0.3) / 0.3\right)$ (Christodoulou et al. 2009).

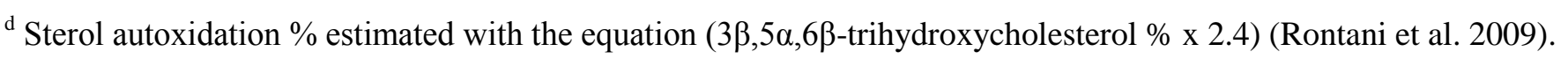

${ }^{\mathrm{e}}$ Obtained from the pseudo first order kinetic of $\Delta^{4}-3 \beta, 6 \alpha / \beta$-dihydroxysterol production. 
Table 3. Chlorophyll, phytol and palmitoleic first-order degradation rate constants, chlorophyll per cell, carotenoid, and sterol relative percentage of photooxidation for Chaetoceros neogracilis grown at similar temperature $\left(7^{\circ} \mathrm{C}\right)$ but different irradiances, before being photodegraded in the same conditions

\begin{tabular}{|c|c|c|c|c|c|c|c|c|c|c|c|c|c|c|}
\hline 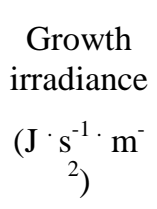 & $\begin{array}{l}\text { Chlorophyll } \\
\text { per cell } \\
\left(\mu \mathrm{g} \cdot \mathrm{cell}^{-1}\right)\end{array}$ & Carotenoids $^{\mathrm{a}}$ & $\begin{array}{l}\mathrm{k}_{\text {Chlorophyll }}{ }^{\mathrm{b}} \\
\left(\mathrm{KJ}^{-1} \cdot \mathrm{m}^{2}\right)\end{array}$ & $\begin{array}{l}\mathrm{r}^{2} \\
\mathrm{n}\end{array}$ & $\begin{array}{c}\mathrm{k}_{\text {Phytol }}^{\mathrm{b}} \\
\left(\mathrm{KJ}^{-1} \cdot \mathrm{m}^{2}\right)\end{array}$ & $\begin{array}{l}\mathrm{r}^{2} \\
\mathrm{n}\end{array}$ & $\begin{array}{c}\mathrm{k}_{\mathrm{C} 16: 1}^{\mathrm{b}} \\
\left(\mathrm{KJ}^{-1} \cdot \mathrm{m}^{2}\right)\end{array}$ & $\begin{array}{l}\mathrm{r}^{2} \\
\mathrm{n}\end{array}$ & $\begin{array}{l}\mathrm{k}_{\text {Cholesterol }}{ }^{\mathrm{b}} \\
\left(\mathrm{KJ}^{-1} \cdot \mathrm{m}^{2}\right)\end{array}$ & $\begin{array}{l}\mathrm{r}^{2} \\
\mathrm{n}\end{array}$ & $\begin{array}{c}\text { Cholesterol } \\
\text { photo- } \\
\text { oxidation } \\
(\text { relative } \%)^{\mathrm{c}}\end{array}$ & $\begin{array}{l}\mathrm{k}_{\text {Campesterol }}{ }^{\mathrm{b}} \\
\left(\mathrm{KJ}^{-1} \cdot \mathrm{m}^{2}\right)\end{array}$ & $\begin{array}{l}\mathrm{r}^{2} \\
\mathrm{n}\end{array}$ & $\begin{array}{c}\text { Campesterol } \\
\text { photo- } \\
\text { oxidation } \\
(\text { relative } \%)^{\mathrm{c}}\end{array}$ \\
\hline 6.5 & $6.38 \times 10^{-7}$ & 8.42 & $3.80 \times 10^{-4}$ & $\begin{array}{c}0.96 \\
7\end{array}$ & $2.05 \times 10^{-4}$ & $\begin{array}{c}0.98 \\
6\end{array}$ & $1.06 \times 10^{-4}$ & $\begin{array}{c}0.96 \\
6\end{array}$ & $4.04 \times 10^{-5}$ & $\begin{array}{c}0.92 \\
5\end{array}$ & $93 \pm 5$ & $4.03 \times 10^{-5}$ & $\begin{array}{c}0.89 \\
5\end{array}$ & $94 \pm 4$ \\
\hline 13 & $5.45 \times 10^{-7}$ & 7.63 & $3.70 \times 10^{-4}$ & $\begin{array}{c}0.99 \\
7\end{array}$ & $1.90 \times 10^{-4}$ & $\begin{array}{c}0.98 \\
6\end{array}$ & $1.12 \times 10^{-4}$ & $\begin{array}{c}0.95 \\
6\end{array}$ & $8.39 \times 10^{-5}$ & $\begin{array}{c}0.91 \\
6\end{array}$ & $92 \pm 2$ & $5.91 \times 10^{-5}$ & $\begin{array}{c}0.79 \\
6\end{array}$ & $88 \pm 3$ \\
\hline 36 & $4.55 \times 10^{-7}$ & 7.40 & $1.99 \times 10^{-3}$ & $\begin{array}{c}0.92 \\
5\end{array}$ & $2.80 \times 10^{-4}$ & $\begin{array}{c}0.94 \\
7\end{array}$ & $1.85 \times 10^{-4}$ & $\begin{array}{c}0.95 \\
7\end{array}$ & $9.05 \times 10^{-5}$ & $\begin{array}{c}0.93 \\
5\end{array}$ & $91 \pm 1$ & $1.24 \times 10^{-4}$ & $\begin{array}{c}0.99 \\
6\end{array}$ & $87 \pm 1$ \\
\hline
\end{tabular}

\section{$\left(7^{\circ} \mathrm{C}\right.$ and $\left.36 \mathrm{~J} \cdot \mathrm{s}^{-1} \cdot \mathrm{m}^{-2}\right)$}

${ }^{a}$ Concentration of carotenoid as a percentage of total pigment concentration (chlorophyll and carotenoid).

${ }^{\mathrm{b}}$ Pseudo first order degradation rate constant

${ }^{c}$ Sterol photooxidation \% (relative to autoxidation) estimated with the equation $\left(\Delta^{4}-3 \beta, 6 \alpha / \beta\right.$-dihydroxycholesterols $\%$ x $\left.(1+0.3) / 0.3\right)($ Christodoulou et al. 1999). 


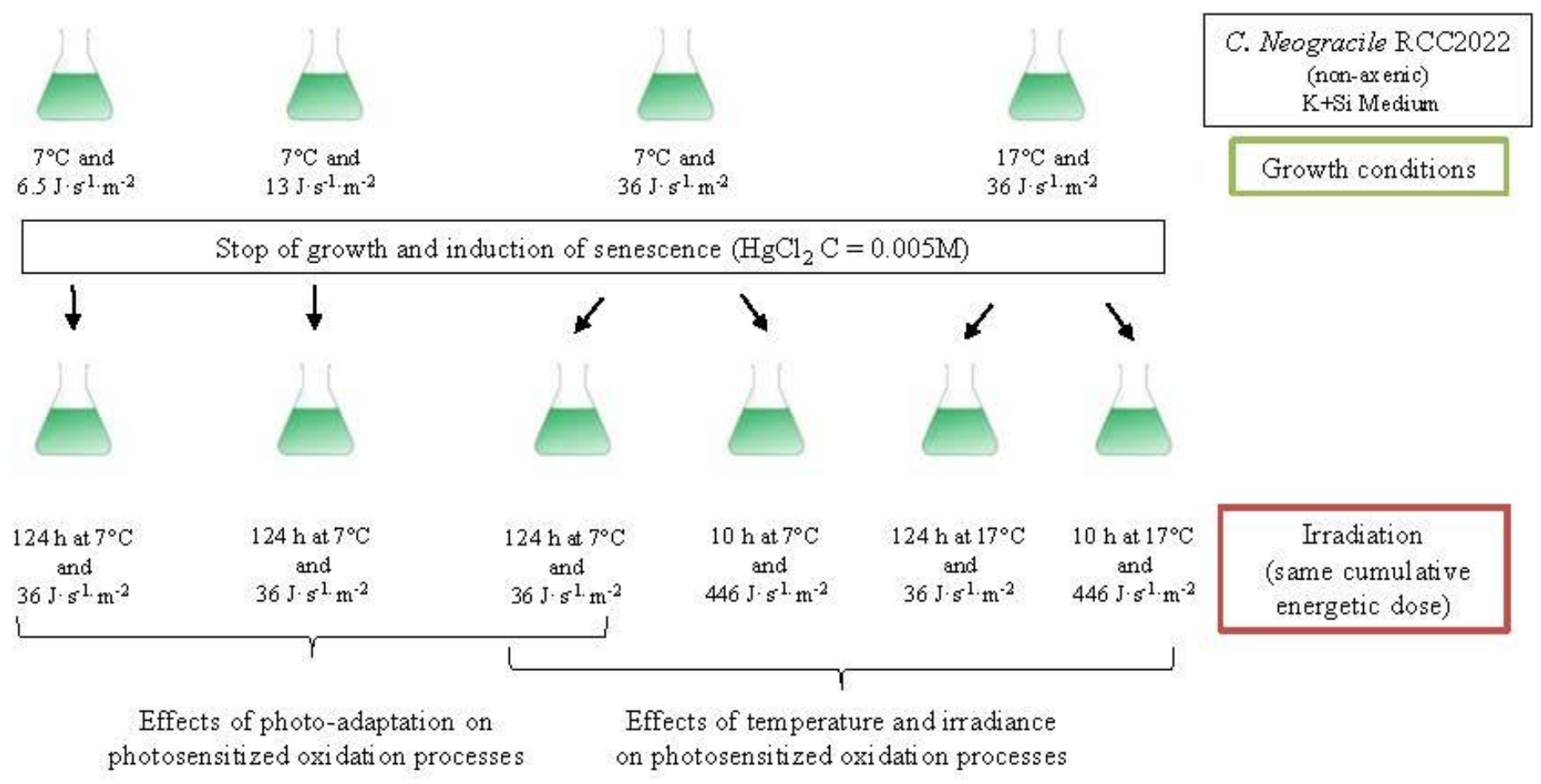




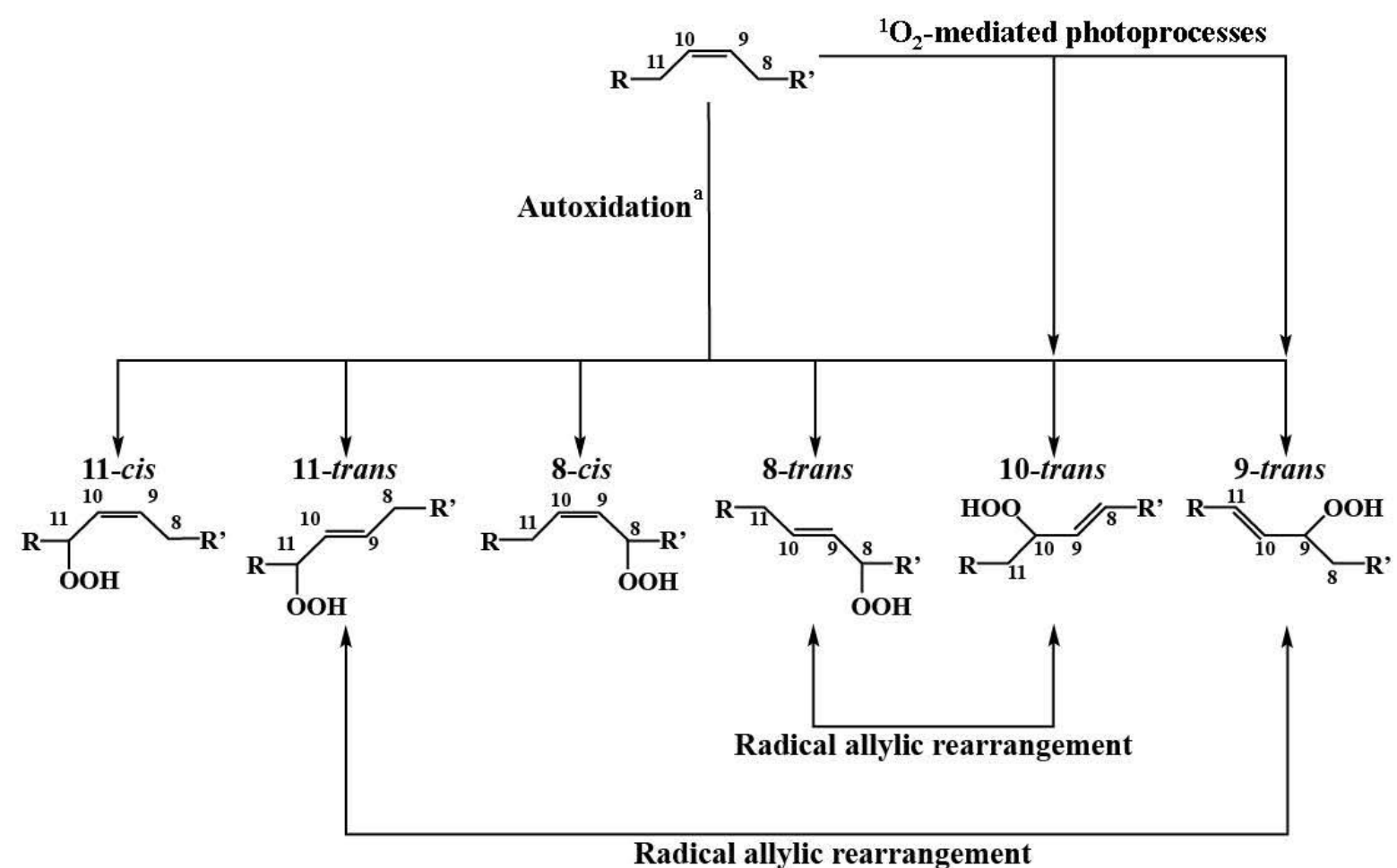

$\mathrm{R}=-\left(\mathrm{CH}_{2}\right)_{4}-\mathrm{CH}_{3}$

$\mathbf{R}^{\prime}=-\left(\mathrm{CH}_{2}\right)_{6} \mathbf{C O O H}$

a 9-cis and 10-cis hydroperoxides (which represent less than $1 \%$ of autoxidation products) have been omitted in order to simplify the scheme. 

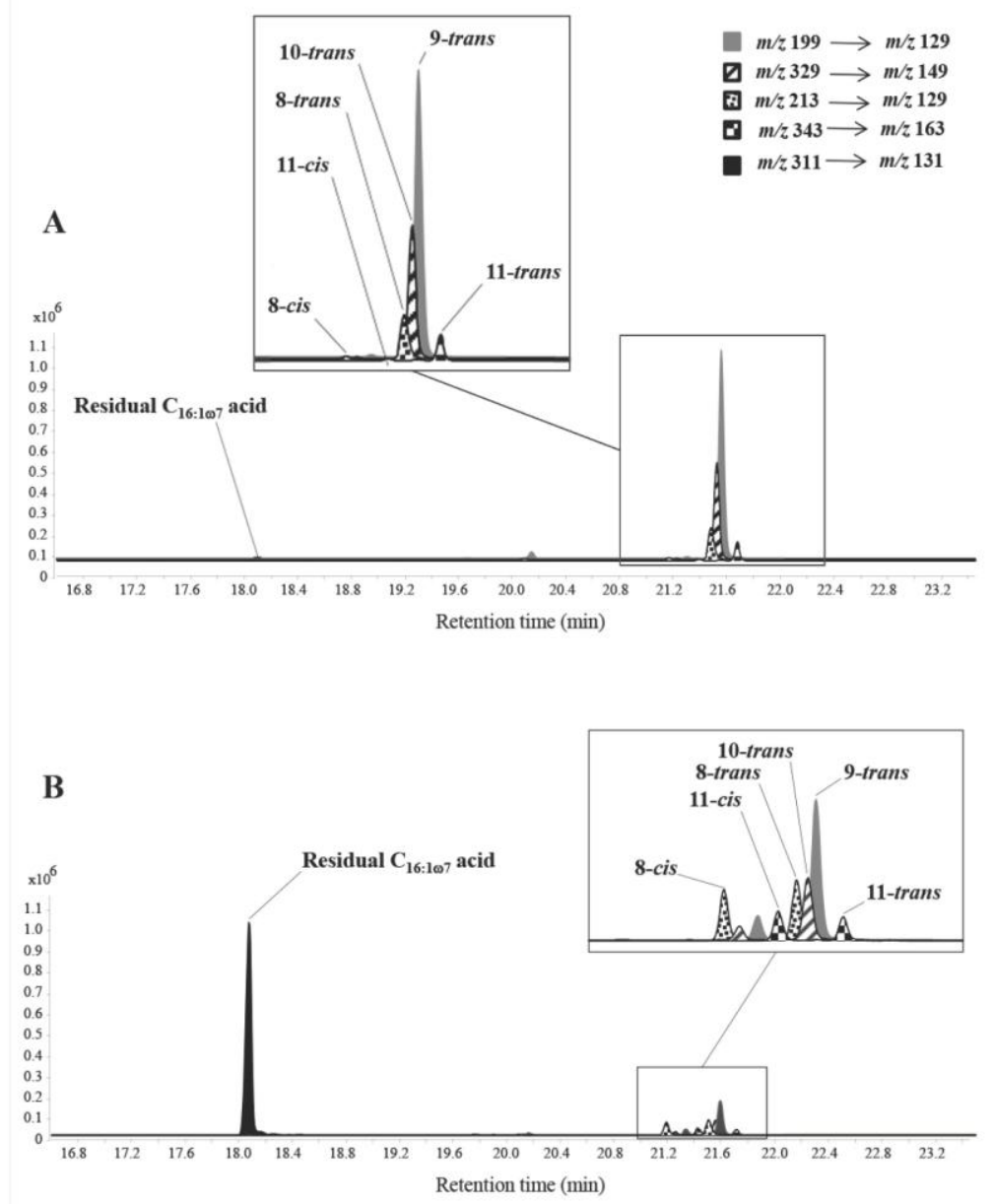